\title{
Erratum to: Genomic DNA extraction from herbarium samples of Cunila D. Royen ex L. (Lamiaceae) and Polygala L. (Polygalaceae)
}

Gustavo Agostini $\cdot$ Raquel Lüdtke •

Sergio Echeverrigaray · Tatiana Teixeira de Souz-Chies

Published online: 9 February 2011

(C) Springer Science+Business Media B.V. 2011

Erratum to: Conservation Genet Resour (2011) 3:37-39

DOI 10.1007/s12686-010-9277-3

On page 1, last paragraph, 8th line, the following sentence should be replaced 'The supernatant was discarded and the DNA was precipitated in presence of isopropanol and stored at $-20^{\circ} \mathrm{C}(1 \mathrm{~h})^{\prime}$

The online version of the original article can be found under doi:10.1007/s12686-010-9277-3.

\section{G. Agostini · R. Lüdtke}

Programa de Pós-Graduação em Botânica, Departamento de Botânica, Universidade Federal do Rio Grande do Sul, Prédio 43433, Porto Alegre, RS CEP 91501-970, Brazil

\section{Present Address:}

R. Lüdtke

Departamento de Botânica, Instituto de Biologia,

Universidade Federal de Pelotas-UFPel, Campus Capão

do Leão, Caixa Postal 354, Pelotas, RS, Brazil

S. Echeverrigaray

Instituto de Biotecnologia, Universidade de Caxias do Sul,

R. Francisco Getúlio Vargas, 1130, Petrópolis, PO Box 1352,

Caxias do Sul, RS CEP 95001-970, Brazil

G. Agostini $(\bowtie) \cdot$ T. T. de Souz-Chies

Departamento de Botânica, Instituto de Biociências,

Universidade Federal do Rio Grande do Sul, Av. Bento

Gonçalves, 9500, Bloco IV, Prédio 43433, Porto Alegre,

RS 91501-970, Brazil

e-mail: sabonim.radan@gmail.com and should now read as:

'The supernatant was transferred to a new tube and the DNA was precipitated in presence of isopropanol and stored at $-20^{\circ} \mathrm{C}(1 \mathrm{~h})^{\prime}$. 